The Psychology of Literacy 



\section{The Psychology of Literacy}

SYLVIA SCRIBNER

MICHAEL COLE 
Copyright $\odot 1981$ by the President and Fellows of Harvard College All rights reserved

Printed in the United States of America

Library of Congress Cataloging in Publication Data

Scribner, Sylvia, 1925-

The psychology of literacy.

Bibliography: p.

Includes index.

1. Language and culture-Liberia. 2. IlliteracyLiberia. 3. Writing. 4. Psycholinguistics. 5. Vai language. 6. Vei (African tribe) I. Cole, Michael, 1938- joint author. II. Title.

P35.5.L5S3 401'.9 81-607

ISBN 0-674-72115-2 AACR2 
To David Scribner and Sheila Cole 
